\section{B A Institute of \\ YK Business Administration \\ 光 \\ Karachi \\ Leadership and Ideas for Tomorrow}

\section{Business Review}

Volume 7 Issue 2 July-December 2012

7-1-2012

\title{
The impact of training and motivation on performance of employees
}

Muhammad Ikhlas Khan

International Islamic University, Islamabad, Pakistan

Follow this and additional works at: https://ir.iba.edu.pk/businessreview

Part of the Social and Behavioral Sciences Commons

(c) (7)

This work is licensed under a Creative Commons Attribution 4.0 International License.

\section{Recommended Citation}

Khan, M. I. (2012). The impact of training and motivation on performance of employees. Business Review, 7(2), 84-95. Retrieved from https://doi.org/10.54784/1990-6587.1205

This article is brought to you by iRepository for open access under the Creative Commons Attribution 4.0 License and is available at https://ir.iba.edu.pk/businessreview/vol7/iss2/6. For more information, please contact irepository@iba.edu.pk. 


\title{
ARTICLE
}

\section{The Impact of Training and Motivation on Performance of Employees}

\author{
Muhammad Ikhlas Khan \\ International Islamic University, Islamabad, Pakistan
}

\begin{abstract}
This research aim is to study the impact of training on performance of employees. There are various factors like training, motivation, technology, management behavior, working environment, where each factor contributes to overall employee performance. Highly contributing factors are those having relative importance given by employees. This study concludes that training contributes greatly to employee's performance in comparison with other factors like motivation, technology, management behavior, working environment. There is positive relationship between the employee's performance and training and motivation. The study shows that training and motivation has positive impact on performance of employees. This study concludes that organization having good training plans for employees can enhance the performance of employees All the organization that wants to enhance their employee performance should focus on training as it also motivate employees to achieve higher performance levels.
\end{abstract}

Key words: Employee's performance, Training, Motivation

\section{Introduction}

The possible influence of concessions and takeovers on corporate performance will be addressed in the following analysis data set and use a large new dataset on employee held stock in US public companies... (Blasi et al, 1996) We define significant employee ownership as... (Jackson et al, 1997)...The definition of employee performance as the logarithm of net sales per employee was consistent with prior empirical work (Huselid, 1995). ... Net sales per employee is an incomplete measure of firm performance, however, it does not reflect overall firm profitability. ...

Employee performance management is a process that companies use to ensure their employees are contributing to producing a high quality product or service. Employee performance management encourages the employee to get involved in the planning for the company, and therefore anticipates by having a role in the process the employee will be motivated to perform at a high level. Performance is the ratio of output to input. Performance is a process of continuous improvement in the production/supply of quality output/service through efficient and effective use of inputs, with emphasis on teamwork for the betterment of all. Training is needed to increases the performance of employees, if 
employees are trained they will be well aware of their job specifications, skill needed to perform job well and would be able to use new technology. Then their motivation level will be increased, which will also be beneficial in enhancement of performance, working environment and management behavior will also result in the maximized performance which will be help to achieve the organization goals effectively. Competitiveness is based upon the concept of performance, which is very closely linked to that of training. As every organization through out the world wants to compete against their competitors, they must increase their performance to do so. When employees are given training they feel some betterment in their own performance and hence work more hard to achieve personal and organizational goals. Training can be define as; Training is a learning process that involves the acquisition of knowledge, sharpening of skills, concepts, rules, or changing of attitudes and behaviors to enhance the performance of employees. This research will be helpful to understand the importance of training and the effect of training on performance which is positive. Research will also throw light on other factors of performance such as motivation, working conditions, management behavior and technology. Research will suggest the better way of training to management and also suggest that organization must give importance to training of employees and training must be for sufficient duration.

\section{Literature Review}

Bartel (1994) looked at the link between training and performance using around 150 firms from another surveys of employers, the Columbia business school survey. Becker (1975) defined general training as the type of training that raises performance by equal amounts in the firm where it was provided and in other firms. In contract, specific training only raises performance in the firm providing it.

(Puffers and Cohen, 1984) when firm specific skills are needed to conduct work effectively, the firm must make training investment so worker can develop specific skills. Once workers obtain the firm specific skills needed for effectiveness on the job. The employer must pay wages reflecting workers higher performance level. Often this is accomplished by promoting the employees on a career ladder as each new set of specific skill is attained.

A third limitation of this work is the failure to directly measure the underlying mechanisms through which work-life programs increased performance. Specifically, argued that work-life programs enhanced performance by attracting and retaining high quality employees, by reducing the extent to which work life conflicts interfere with work. (Greenhaus and Parasuraman, 1999; Lobel and kossek, 1996; lobel 1999)

The Detroit performance center had virtually no lasting impact but staff training and development received little continued attention.

Muhammad Ehsan Malik (January, 2011) tells that the performance of male and female are equally contributed towards the achievement of a goal. Both male and female are equally responsible and the responsibility of both have equal importance in the organization. 
The employee's performance directly influences the organizational effectiveness. Man and woman should motivate equally. Eliminate the inequality and give equal importance to both. The employee's performance increased when they involved in decision making of the organization... (Salman naseer, January, 2011)

Researdes have identify that the employees motivations are increased when the organization empower them. When they are empowered, then they did well. Kreitner descibes(1995) the psychological way that gives the purpose and direction to behavior.

According to Buford, Bedeian, \& Lindner (1995) there is a predisposition to behave in a purposive manner to achieve specific, unmet needs and according to Bedeian (1993), an internal drives to satisfy an unsatisfied need and the will to achieve.

\section{Motivation Theories}

Getting people to do their best work, even in trying circumstances, are one of managers' most enduring and slippery challenges. Indeed, deciphering what motivates us as human beings is a centuries-old puzzle. Some of history's most influential thinkers about human behavior among them Aristotle, Adam Smith, Sigmund Freud, and Abraham Maslow have struggled to understand its nuances and have taught us a tremendous amount about why people do the things they do.

Maslow hierarchy of needs (1943) discussed five levels of employee needs, physiological, safety, social, ego, and self- actualizing. According to Maslow lower level needs had to be satisfied before the next higher level need would motivate employees. Herzberg, categorized motivation into two factors: motivators and hygienic (Herzberg, Mausner, \& Snyderman, 1959). Motivator or intrinsic factors, such as achievement and recognition, produce job satisfaction. Hygiene or extrinsic factors, such as pay and job security, produce job dissatisfaction.

Vroom's theory is based on the belief that employee effort will lead to performance and performance will lead to rewards (Vroom, 1964).

Rewards may be either positive or negative. The more positive the reward the more likely the employee will be highly motivated. Conversely, the more negative the reward the less likely the employee will be motivated. Adams' theory states that employees strive for equity between themselves and other workers. Equity is achieved when the ratio of employee outcomes over inputs is equal to other employee outcomes over inputs (Adams, 1965).

Skinner's theory simply states those employees' behaviors that lead to positive outcomes will be repeated and behaviors that lead to negative outcomes will not be repeated (Skinner, 1953).

Managers should positively reinforce employee behaviors that lead to positive outcomes. Managers should negatively reinforce employee behavior that leads to negative outcomes. 


\section{Training}

The major premise of performance education and training is that troubled program such as those have cited, have replied primarily on formal management and education and experiential learning (on the job) to address the question above. Yet management is a deceptive concept even the administrator who work through masters degree in administration may never be exposed to some of the material critical to his daily organization problem. Administer with a formal education in the field of education may not have maintain its currency and perhaps majority of the manager in public organizations obtain degrees in such field as law, engineering, medicine, or humanities the rather then systematical educated or trained performance management. Other Birmingham companies focus on creating those same results within different industries. For instance, Work Matters Executive and Corporate Coaching specializes in training leaders and managers within the insurance and financial services industry, and Strategic Visions Inc. finds most of its business concentrated within the health-care sector.

Researchers identifie that employee training is a learning experience that seeks relatively permanent change in employees that there improve job performance. Thus training involves changing skills, knowledge, attitude, or behavior. Determination of the organization need, the work to be done and the skill necessary to complete this work, training program should naturally. Once identify deficiencies lies, have a grasp of the extent and nature of the training needs. (James G. Maxham, 2008)

Identifies if deficiencies in performance occur it does not necessarily follow that the manager should take corrective action. It is important to put training in to perspective. Training is costly, rather judge training by its contribution to performance, where performance is function of skills. (Annalisa Cristini, 2004)

Identifies that training goal must be established. Organization explicitly states its desire result for each employee. It is not adequate to say we want to change employee skill attitude or behavior. Organization clarifies what is to change and by how much. The goal should be tangible, verifiable, timely, and measurable. (Tor Eriksson 2006)

\section{Objectives of the Study}

The main objectives of this research are as follows.

- To know the impact of training and motivation on performance of employees in the organizations

- To examine the role of training and motivation in enhancement of employee's performance

- To gauge the correlation between training and performance of employees

- To get the results in meaningful way that can help the organizations in future

\section{The Problem Statement}

How training influences the performance of employees in the organizations? 


\section{Theoretical Framework}

The following variables have been identified and labeled as independent variables and dependent variable.

\section{Performance}

Performance is the dependent variable which depends upon training of employees. Literature review also reveals that performance is dependent variable and it is increased by providing effective training. There are some other variables or factors that affect the performance of employees are as given below.

\section{Motivation}

The motivation is very important in influencing the employees to accomplish individual as well as the organizational goals. This inner drive motivates the employees to form and exhibit the purposive behavior to achieve specific, unmet needs. This little encouragement on the part of organization enables them to accomplish their goals efficiently by acknowledging employees on their work and effort, providing them good work environment, considering their needs and forming pleasant job design. The motivation increases performance.

\section{Training}

Training is the independent variable in this research. Literature review suggests that training of employees has a deep effect on the performance of employees. There is direct relationship between training and performance i.e. training increases the performance.

Figure 1 shows the relationship between dependent and independent variables.

Fig.1

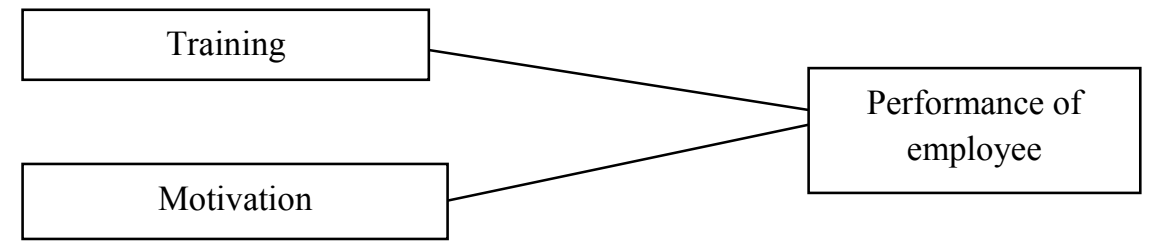

$\mathrm{P}=\mathrm{a}+\mathrm{BT}+\mathrm{BM}$

Where:

$\mathrm{P}=$ Employee performance

$\mathrm{T}=$ Training

$\mathrm{M}=$ Motivation 


\section{Hypothesis Development}

The hypotheses are developed in this research as follows.

H1: Training increases the performance of employees.

H2: Motivation increases performance of employees.

\section{Methodology}

This study aims to identify the impact of motivation and training on performance of employee and determines the other factors that affect the performance. The prime focus of this study is to carry out to identify the effect of training on performance of employee. The contribution of other factors is enhancing the performance of employees. To measure the relationship and identify the impact of training on employee's performance, some statistical tools or techniques are applied on data like Pearson correlation and regression analysis through SPSS software.

\section{Sample}

Respondents for the questionnaire were randomly chosen from one institute and one bank that are use to train their employees. The chosen bank and institute was Habib Bank and Federal Urdu University of Arts Science and Technology Islamabad. A sample of 100 employees from the above mentioned organization is taken.

\section{Data Collection Instruments}

The principal data collection instrument is structured questionnaire, chosen to determine the performance of employees. The questionnaire consisted of different factors that could affect performance.

\section{Procedure}

The procedure used for data analysis is significant. The instrument used for data collection is structured questionnaire which is the primary source of data collection. The data has been dealt using the SPSS software. After compiling the output of questionnaires the variables are entered in software and the data is also entered. There are some statistical techniques are applied on data to find out the results. In the first instant reliability statistics analysis measured to find out the data is reliable or not. In the second instance descriptive statistics analysis is measured to check the mean and standard deviation for the variables. Correlation is the statistical technique which is applied on data to gauge the relationship between the training, motivation and employees performance. Regression is the statistical technique applied on data to measure the impact of training and motivation on performance of employees in the organizations. 


\section{Research Model}

The research model is developed on the basis of earlier research studies; we have included the variables are as performance, training and motivation.

Tested Equation is as follows:

$\mathrm{Y}=\alpha+\beta_{1} \mathrm{X}_{1}+\beta_{2} \mathrm{X}_{2}$

$\mathrm{Y}=$ Performance

$\mathrm{X} 1=$ Training

$\mathrm{X} 2=$ Motivation

\section{Research Findings}

a) Reliability Statistics Analysis

Table 1

\begin{tabular}{|c|c|c|}
\hline Variables & Chronbach's Alpha & N of Items \\
\hline Performance & 0.376 & 3 \\
\hline Training & 0.679 & 5 \\
\hline Motivation & 0.475 & 5 \\
\hline
\end{tabular}

Table 1 show the reliability analysis of all the variables, the value of chronbach's alpha 0.376 for performance and 0.679 for training and 0.475 for motivation.

\section{b) Descriptive Statistics Analysis}

Table 2

\begin{tabular}{|c|c|c|c|}
\hline Variables & Mean & Std. Deviation & $\mathrm{N}$ \\
\hline Performance & 1.7700 & 0.48477 & 100 \\
\hline Training & 2.1440 & 0.62609 & 100 \\
\hline Motivation & 2.3720 & 0.61168 & 100 \\
\hline
\end{tabular}

Table 2 provides the information about descriptive statistics of the variables. $\mathrm{N}$ denotes the total number of sample which is taken for analysis. The standard deviation and average is also shown in above table. Performance has the mean of 1.7700 with standard deviation of 0.48477 . The mean of training is 2.1440 and standard deviation is 0.62609 . The standard deviation of motivation is 0.61168 and mean is 2.3720 .

\section{c) Pearson Correlation Analysis}


Table 3

\begin{tabular}{|c|c|c|c|c|}
\hline & & Performance & Training & Motivation \\
\hline \multirow{3}{*}{ Performance } & $\begin{array}{c}\text { Pearson } \\
\text { Correlation }\end{array}$ & 1 & $0.321^{* *}$ & 0.092 \\
\hline & Sig. (2-tailed) & & .001 & .365 \\
\hline & $\mathrm{N}$ & 100 & 100 & 100 \\
\hline \multirow{3}{*}{ Training } & $\begin{array}{c}\text { Pearson } \\
\text { Correlation }\end{array}$ & $0.321^{* *}$ & 1 & $0.214^{*}$ \\
\hline & Sig. (2-tailed) & .001 & & .032 \\
\hline & $\mathrm{N}$ & 100 & 100 & 100 \\
\hline \multirow{3}{*}{ Motivation } & $\begin{array}{c}\text { Pearson } \\
\text { Correlation }\end{array}$ & 0.092 & $0.214^{*}$ & 1 \\
\hline & Sig. (2-tailed) & .365 & .032 & \\
\hline & $\mathrm{N}$ & 100 & 100 & 100 \\
\hline \multicolumn{5}{|c|}{ **. Correlation is significant at the 0.01 level (2-tailed). } \\
\hline \multicolumn{5}{|c|}{ *. Correlation is significant at the 0.05 level (2-tailed). } \\
\hline
\end{tabular}

Table 3 shows the correlation between the independent and dependent variables. According to the calculated values, performance of employees has positive correlated with training and motivation, as 0.321 and 0.092 respectively. On the other hand, positive correlation is found between training and motivation. It is concluded that if employees are adequately provided training, they perform better and their performance is increased as proven by primer data. Training, motivation, (if provided effectively) has a Positive effect on performance.

\section{Pearson Correlation Coefficient: Hypothesis Testing}

There are two hypotheses that are being tested:

H1: Training increases the performance of employees

$\mathrm{H} 2$ : motivation increases performance of employees

The table below is a summary of hypothesis testing which indicates the relations of employee's performance and the two independent variables.

Table 4

\begin{tabular}{|c|c|c|c|}
\hline Hypothesis & Variables & Pearson Correlation & Relationship \\
\hline $\mathrm{H}_{1}$ & Training & 0.321 & Positive \\
\hline
\end{tabular}




\begin{tabular}{|l|l|l|l|}
\hline $\mathrm{H}_{2}$ & Motivation & 0.092 & Positive \\
\hline
\end{tabular}

As per relationship between the independent variables, based on Pearson Correlation, the values of relation between independent variables in this study are less than 0.70 indicating that correlations between each of independent variables are not too high. But the relationship is found positive and training and motivation increases more the performance of employees. There is direct relationship between employee's performance and both training and motivation. The hypothesis $\mathrm{H}_{1}$ and $\mathrm{H}_{2}$ are accepted.

\begin{tabular}{|c|c|c|c|c|c|}
\hline Model & $\mathrm{R}$ & R Square & Adjusted R Square & Std. Error of the Estimate & $\mathrm{N}$ \\
\hline 1 & $0.322^{\mathrm{a}}$ & 0.104 & 0.085 & 0.46369 & 100 \\
\hline \multicolumn{7}{|l}{ a. Predictors: (Constant), Motivation, Training } \\
\hline
\end{tabular}

\section{d) Regression Statistics Analysis}

Table 5

Table 5 provides a summary output about regression statistics and number of observations to be taken. According to above calculations, regression statistics consist of 100 observations, in which multiple $\mathrm{R}$ has a value of 0.322 and $\mathrm{R}$ square has 0.104 accordingly. The value of adjusted $\mathrm{R}$ square is 0.085 . This calculation shows standard error of .46369 , which is acceptable. The value of $\mathrm{R}$ indicates that there is positive weak to moderate relationship among the employee's performance and independent variables. The value of $\mathrm{R}$ square shows that $10.4 \%$ of total variation in employee's performance is explained by training and motivation. Model 1 explains $10.4 \%$ variation is explained by the given variables and the rest of variance is explained by the other factors or variables which are not included in this model. So the remaining variance is unexplained.

\section{e) Coefficients (a)}

\begin{tabular}{|c|c|c|c|c|c|c|}
\hline & \multirow{2}{*}{ Model } & \multicolumn{2}{|c|}{ Unstandardized Coefficients } & \multirow{2}{*}{$\begin{array}{c}\text { Standardized Coefficients } \\
\text { Beta } \\
\end{array}$} & \multirow{2}{*}{$\mathrm{t}$} & \multirow{2}{*}{ Sig. } \\
\hline & & $\mathrm{B}$ & Std. Error & & & \\
\hline \multirow{3}{*}{1} & (Constant) & 1.201 & 0.224 & & 5.363 & .000 \\
\hline & Training & 0.245 & 0.076 & 0.316 & 3.210 & .002 \\
\hline & Motivation & 0.019 & 0.078 & 0.024 & 0.243 & .808 \\
\hline
\end{tabular}


Table 6

Table 6 shows the beta values for variables and constant in the model. The value of beta is 0.245 for training and 0.019 for motivation which are independent variables. The value of beta basically shows the expected change or increase in dependent variable for change or increase of 1 unit increase in independent variable. It means that both the variables training and motivation contributes towards the employee's performance positively, because negative beta value is not found. The impact or influence of training and motivation is positive on performance of employees in the organizations.

The research model is developed as follows.

$\mathrm{Y}=\alpha+\beta_{1} \mathrm{X}_{1}+\beta_{2} \mathrm{X}_{2}$

Where $\mathrm{Y}$ denotes Performance, $\mathrm{X}_{1}$ denotes training, $\mathrm{X}_{2}$ denotes motivation, $\alpha$ denotes the constant value in the model.

$\mathrm{Y}=1.201+0.245 \mathrm{X}_{1}+0.019 \mathrm{X}_{2}$

\section{Conclusion}

This study is conducted to identify the affect of certain factors on the employee's performance. The study found that there are two factors influencing employee's performance that are training and motivation in the organizations. The relationship of independent variables with dependent variables is also examined. All factors, two factors found to be positively related with performance of employees. This study provides some information regarding that two factors are positively correlated with performance of employees in the given organizations. All these factors have direct relationship with performance. An increase in any of independent variable will cause increase in performance. There are two factors (training and motivation), each factor play a key role in increase in overall performance, and all these factors influence the performance of employees. The chosen bank and institute is Habib Bank and Federal Urdu University of Arts Science and Technology Islamabad. A sample of 100 employees from the above mentioned organization is taken. The principal data collection instrument is structured questionnaire, chosen to determine the performance of employees. Training contributes greatly to performance, after finding the answers of questionnaires some statistical techniques are applied like Pearson correlation and regression analysis to find out the results in meaningful way that can help the organizations in future. The statistical techniques are applied on data through SPSS software and get the results. All the correlation results are positive so that on the basis of those results training increases the performance and performance have positive relationship with training, motivation. The research concludes that if the organization having good training plans for employees can enhance the performance of employees that is helpful in increase in performance of employee as well as of organization. All the organization that wants to enhance their employee performance should focus on training, motivation of employees to achieve higher performance levels. This study concludes that training contributes greatly to employee's performance in comparison with other factors like motivation, technology, management behavior, working environment. There is positive relationship between the employee's performance 
and training and motivation. This study shows that training and motivation have expected positive impact on performance of employees in the organizations. This study can helpful for the above mentioned organizations in future. It will also be helpful for other organizations in future especially related to higher education and banking sectors. 融

\section{References}

Adams, J. S. 1965, Inequity in social exchange.\| In L. Berkowitz (ed.), Advances in experimental social psychology. New York: Academic Press

Barrett, A., \& O'Connell, Philip, J., 2001, Does Training Generally Work? The Returns to In-Company Training, Industrial and Labor Relation Review, Vol. 54, No. 3, p. 647-662 by Cornell University

Bedeian, A. G., 1993, Management, 3rd Edition, New York, Dryden Press

Becker, 1975, Does Training Generally Work? The Returns to In-Company Training: Industrial and Labor Relation Review, p. 649, Vol. 54, No. 3 (April 2001) By Cornell University

Becker, Gary S., 1975, Human Capital, 2nd Ed., and New York: Columbia University Press.

Blasi, J., Conte, M., \& Kruse, D., 1996, Employee Stock Ownership and Corporate Performance among Public Companies, Industrial and Labor Relation Review, Vol. 50, No. 1 by Cornell University

Blasi, J., Conte, M., 1996, Industrial \& Labor Relations Review - questia.com

Greenhaus and Parasuraman, 1999; Lobel and kossek, 1996; lobel 1999, Marc Holzer David Tatge, Source: Public Performance review, Vol. 2, No 4, (autumn, 1977) p. 4

Herzberg, F., Mausner, B., \& Snyderman, B. B., (1959), the motivation to work, New York: john Wiley \& Sons

Holzer, Harry J., Richard N. Block, Marcus Cheatham, and Jack H. Knott., 1993, Are Training Subsidies for Firms Effective? The Michigan Experience

http://birmingham.bizjournals.com/birmingham/stories/2001/10/22/focus1.html, Training firms help companies increase profitability, Performance, Access date 6-7-2009

Industrial and Labor Relations Review, Vol. 46, No. 4 (July), pp. 625-36.

Huselid, M. A., Jackson, S. E., \& Schuler, R. S., 1997, Technical and Strategic Human

Huselid, Mark A. 1996. "The Impact of Human Resource Management Practices on Turnover, Pro- ductivity, and Corporate Financial Performance." Academy of Management Journal, Vol. 38, No.3 (June), pp. 635-72. 
Jantti, M., Bratsberg, B., Raaum, O., Naylor, R., Bjorklund, A., Eriksson T., Osterbacka, Eva., 2006, Centre for Labour Market and Social Research (CLS); University of Aarhus Department of Economics

Kreitner, R., 1995, Management, 6th ed., Boston, Houghton Mifflin Company

Malik, M. E., Ghafoor, M. M., Naseer, S., 2011, Organizational effectiveness: A case study of telecommunication and banking sector of Pakistan, Far East Journal of Psychology and Business, Vol. 2, No. 1

Marc Holzer David Tatge, Source: Public Performance review, Vol. 2, No 4, (Autumn, 1977) p. 3

Maslow, A. H., 1943, a theory of human motivation. Psychological Review, July 1943. 370-396

Puffers and Cohen, 1984, Research Notes and Commentaries, The Impact of Work life programs on Firm Performance, p. 1225, Vol. 21, No. 12, (Dec 2000 ) John Wily \& sons Resource Management Effectiveness as Determinants of Firm Performance, The Academy of Management Journal, Vol. 40, No. 1, p. 171-188

Research Notes and Commentaries, the Impact of Work life programs on Firm Performance, p. 235, Vol. 21, No 12, (Dec, 2000) John Wily \& sons

Shahzad, K., Sarmad, M., Abbas, M., \& Khan, M. A., 2011, Impact of Emotional Intelligence (EI) on employee's performance in telecom sector of Pakistan, African Journal of Business Management, Vol. 5, No. 4, pp. 1225-1231

Skinner, B. F., 1953, Science and Human Behavior, New York: Free Press

Vroom, V. H., 1964, Work and motivation. New York: Wiley

Let us think of the Latin saying that goes:

Nemo vi rest qui mundum non reddat

meliorem?

"What man is a man who does not make the world better?" 